\title{
Predyspozycje i możliwości zatrudnienia a motywacja wyboru kierunku studiów przez studentów nauk humanistycznych Uniwersytetu Rzeszowskiego i nauk ścisłych Politechniki Rzeszowskiej
}

\section{KEYWORDS}

skills, interests, education, motivation, work

\begin{abstract}
Zbigniew Chodkowski, Predyspozycje i możliwości zatrudnienia a motywacja wyboru kierunku studiów przez studentów nauk humanistycznych Uniwersytetu Rzeszowskiego i nauk ścisłych Politechniki Rzeszowskiej [Predispositions and employment opportunities versus the motivation to choose a field of study among students of the humanities at the University of Rzeszów and exact sciences at the Rzeszów University of Technology]. Kultura - Społeczeństwo - Edukacja nr 1(19) 2021, Poznań 2021, pp. 61-80, Adam Mickiewicz University Press. ISSN 2300-0422. DOI 10.14746/kse.2021.19.5
\end{abstract}

Motivation accompanies various human activities from an early age. The basic ones include fun, education and work. These activities are combined in different proportions and depend on the living environment and the interests of the individual. Care, upbringing, family environment and family atmosphere shape the child's perceptions of the world. These factors also affect the individual in terms of making important decisions, which include undertaking education in a university. The human environment, objects, and the same places also imply various motives in creating human behaviour that translates into aspirations to achieve different life goals.

\footnotetext{
* ORCID https://orcid.org/0000-0001-5114-2314.
} 


\begin{abstract}
The article is an attempt to present the impact of humans' predispositions in their fields of interest, their self-assessment of intellectual possibilities, prospects for high -level earnings, employment opportunities in the country and abroad, as well as the curriculum covering subjects that were not difficult in high school and in which the pupil was good on the motives for choosing a major study of students of humanities at the University of Rzeszów and students of exact sciences from Rzeszów University of Technology.
\end{abstract}

\title{
Wprowadzenie
}

Motywacja stanowi jeden $\mathrm{z}$ ważnych czynników determinujących zachowanie człowieka we wszystkich obszarach jego życia, począwszy od edukacji poprzez zabawę i wykonywanie pracy zawodowej. Poszczególne motywy wpływają na realizację potrzeb pierwszego i drugiego rzędu, wielostronny rozwój jednostki, skuteczniejsze osiąganie przez nią zaplanowanych celów. Właściwie zmotywowany człowiek realizuje $\mathrm{z}$ większą ochotą powierzone mu zadania, a uzyskane przy tym efekty przyczyniają się do osiągania pełnej satysfakcji z wykonanej pracy.

Wybór kierunku studiów należy do odpowiedzialnych decyzji młodego człowieka. W większości przypadków ulega on różnym wpływom zarówno domu rodzinnego, jak i szkoły. Z drugiej strony ważną rolę odgrywają uzdolnienia, zainteresowania i chęć rozwoju osobistego i prozawodowego. W literaturze przedmiotu pojawiają się coraz nowsze przykłady badań w zakresie motywacji wyboru kierunku studiów, które są rezultatem różnych oddziaływań.

Środowisko życia dziecka ma zasadniczy wpływ na jego rozwój osobowy zarówno fizyczny, jak i psychospołeczny. Według Bronfenbrennera rodzice odgrywają kluczową rolę w edukacji dzieci, jako jedno z wielu oddziaływań społeczno-kulturowych, do których zaliczyć należy także szkołę i społeczność w różnych kontekstach. Rodzice jako pierwsi odkrywają u dziecka pewne predyspozycje, a przy współpracy ze szkołą i nauczycielami są one wzmacniane i rozwijane. Uzdolnionej jednostce jest łatwiej poszerzać swoje zainteresowania, przy czym osiąganie różnych celów zależy od systematycznej pracy i właściwego kierowania (Bronfernbrenner, 2009, za: Kim, Mok, Seidel, 2020: 1).

Można przyjąć tezę, że na każdym z poziomów edukacji - kulturowym, relacyjnym i operacyjnym - jednostka zdobywa wiedzę i doświadczenia niezbędne do pełnienia ról społecznych, budowania swej tożsamości i koncepcji własnego życia. Tym samym, na każdym poziomie uruchomionych zostaje wiele interakcji, 
prowadzących do dalszych zmian zarówno systemu, jak i poszczególnych jednostek. Pełna realizacja powierzonych jednostce zadań i osiąganie poszczególnych celów zależy od wielu czynników, które mają wpływ w środowisku życia jednostki (Farnicka, Liberska, 2014: 59).

Yeeun Kim i współautorzy odwołują się do teorii systemów ekologicznych Bronfenbrennera, która wyjaśnia w jaki sposób socjalizacja wewnątrz rodziny (rodziców) oraz pomiędzy środowiskami społecznymi i kulturowymi dzieci wpływa na ich rozwój poznawczy i emocjonalny, a także w jakim zakresie jest znaczący w kolejnych etapach procesu edukacji jednostki (Bronfernbrenner, 2009, za: Kim i wspót., 2020: 2).

Angel Mae Mantica i współ. (2020: 124) podkreślają, że rodzina może zainspirować dziecko do dobrych wyników w szkole. Kiedy uczniowie należą do pełnej rodziny, mogą zyskać większą pewność siebie w wykonywaniu zadania. Natomiast studenci, którzy mają pełną rodzinę, są bardziej zachęceni do tworzenia pozytywnego stylu uczenia się w swoich eksploracjach.

Robert Sadowski w swoich badaniach z 2019 r. stwierdza, że zdecydowanym liderem w kategoriach ogólnych czynników motywujących wybór studiów są: zainteresowania kandydata (prawie 19\%), a następnie - łatwość w znalezieniu pracy po studiach (prawie 12\%) i niecałe 10\% - wpływ reklam, działań uczelni (Sadowski, 2019).

Reasumując, autorzy dostrzegają w swoich eksploracjach badawczych przede wszystkim ważność i wpływ perswazji rodziny, tradycji rodzinnych, zainteresowania, możliwość znalezienia pracy na motywację wyboru kierunku studiów.

\section{Predyspozycje człowieka}

Predyspozycja według Słownika języka polskiego PWN oznacza wrodzoną skłonność lub zdolność do czegoś (https://sjp.pwn.pl/sjp/predyspozycja;2572321.html).

Włodzimierz Szewczuk (1997: 991) określa zdolności człowieka jako „układ warunków wewnętrznych danej jednostki, decydujący o poziomie jakości jej osiągnięć w realizowanej przez nią działalności”. Autor wyróżnia zdolności ogólne i specjalne, czyli uzdolnienia (Szewczuk, 1997: 993).

Wincenty Okoń (1998: 463) definiuje zdolność jako możliwość uzyskania spodziewanych wyników podczas wykonywanych różnych czynności, którym towarzyszą określone warunki zewnętrzne. Autor wyjaśnia, że zdolności mają charakter ogólny i zalicza do nich przede wszystkim: spostrzegawczość, sprawność myślenia, pamięć, wyobraźnię, uwagę, a także sprawność motoryczną. Zdolność 
ogólna zależy od: rozwoju pozytywnej motywacji, zainteresowań i postaw oraz od własnej aktywności jednostki.

Natomiast Ricky Griffin (1997: 654) wskazuje na zdolności poznawcze, które dotyczą danej osoby. Mieszczą się one w zakresie inteligentnego myślenia oraz sprawnego analizowania napotykanych sytuacji i zgromadzonych danych. Według badań inteligencja może być również przesłanką indywidualnej twórczości.

Szewczuk (1997: 992), wyjaśnia teorie zdolności, biorąc pod uwagę koncepcję psychiki człowieka jako złożonej aktywności. Za pomocą tejże aktywności człowiek reguluje swoje stosunki z samym sobą, a także ze światem go otaczającym przyrodniczym i społecznym. Każda działalność ludzka angażuje całego człowieka, dlatego też przejawia się to następującymi czynnościami jako:

a) postrzeganie - odbiór informacji bezpośredniej o zdarzeniach;

b) emocja - odbiór informacji o wartości zdarzeń dla człowieka;

c) myślenie - obróbka informacji;

d) uczenie, czyli zapis informacji;

e) finalne ustosunkowanie się do świata, czyli wykonywanie czynności motorycznych.

Wyróżnione aspekty psychicznego funkcjonowania jednostki prowadzą do wyodrębnienia pięciu ogólnych zdolności człowieka i są to odpowiednio: spostrzegawczość, inteligencja, wyuczalność, emotywność, zręczność. Jak podaje autor, na podstawie analizy badań naukowych udowodniono, że w uzdolnieniach i osiągnięciach jednostki decydujące znaczenie ma cały proces biograficzny, a w nim wyszczególnia się wychowanie i zwłaszcza samowychowanie. Otoczenie ma potężny wpływ na uzdolnienia jednostki, ale muszą być spełnione pewne warunki. Jednostka ma przejawiać zainteresowania, które wpływają na jej aktywność i angażują jej osobowość w procesie działalności. Jednostka ma możliwości rozwijania swoich zdolności i ich wzmacniania tylko poprzez systematyczną pracę (Szewczuk 1997: 995).

\section{Charakterystyka motywacji}

Tomasz Kocowski (1993: 384) wyjaśnia motywację jako „ogół procesów w systemie nerwowym, które:

a) przejawiają się tendencją lub przeciwtendencją do ukierunkowanej aktywności;

b) wywołują i pobudzają tę aktywność, tłumiąc inne tendencje;

c) sygnalizują satysfakcją lub dyssatysfakcją stopień zaspokojenia potrzeb lub realizacji zadań". 
Autor dostrzega również różne rodzaje procesów motywacyjnych, które zależą od aktywności człowieka, a ta z kolei jest ukierunkowana na zaspokojenie potrzeb i realizację zadań (Kocowski, 1993: 384).

James Stoner i współ. (2011: 426) charakteryzują motywację jako pewien psychologiczny stan, który przyczynia się do tego, że człowiek w coś się angażuje. Obejmuje ona różne czynniki, które mogą powodować, wytyczać i podtrzymywać zachowania ludzkie, zmierzające w określonym kierunku. Autorzy dodają, że motywacja odnosi się do zachowań ludzkich i mieści między dwiema skrajnościami:

1) działania odruchowe, np. kichnięcie;

2) wyuczone nawyki, np. czyszczenie zębów (Stoner i wspól., 2011: 426).

Natomiast motywacja według Zimbardo i współautorów (2010: 60) to wszystkie procesy, które są zaangażowane w inicjowanie, ukierunkowanie i utrzymanie fizycznych i psychicznych aktywności człowieka. Motywacja wymaga pobudzenia i determinuje jedną z możliwych reakcji, którą jednostka uruchamia w danej konkretnej sytuacji. Każda motywacja obejmuje różne procesy umysłowe, które mają wpływ na działania i na dokonanie różnych wyborów, dlatego też można przyjąć stwierdzenie, że motywacja towarzyszy wielu zachowaniom człowieka.

Janusz Reykowski (1992: 113) podobnie definiuje motywację - jako proces psychicznej regulacji, dzięki któremu formują się dążenia jako tendencja do podejmowania ukierunkowanych czynności na określony cel. Czynności te mogą być powstrzymywane, odraczane lub też modyfikowane. Natomiast funkcją dążeń jest sterowanie czynnościami człowieka w taki sposób, aby doprowadzały one do określonego, zgodnego $\mathrm{z}$ intencją efektu.

Leszek Kozioł wyjaśnia motywację za Michoniem (1981) jako „zespół sił i czynników pobudzających i podtrzymujących człowieka w zachowaniach, które zmierzają do osiągnięcia określonych celów”. Autor zalicza do tych zespołów sił m.in.: potrzeby, popędy, instynkty, aspiracje, a także stany napięć - zwane mechanizmami organizmu ludzkiego. Inną definicję motywacji autor podaje za Stabryłą (1995), stwierdzając, że motywacja jest atrybutem świadomości człowieka jako cechy, która uzasadnia aktywizację działania, bądź jej zaniechanie (Kozioł, 2002: 27).

$\mathrm{Na}$ podstawie podanych definicji stwierdza się, że motywacja zależy w dużej mierze od aktywności człowieka, która może być ukierunkowana na zaspokojenie potrzeb lub realizację zadań i zależy ona od rodzajów procesów motywacyjnych, albowiem mogą one pobudzać aktywność zewnętrzną jako wszelkie działania człowieka, a także aktywność wewnętrzną jako czynności psychiczne, w tym procesy umysłowe (Kocowski, 1993: 384).

Motywacja jako złożony proces składa się z poszczególnych motywów, które częstokroć mogą być sprzeczne z osiąganymi celami. Aczkolwiek każde motywy 
przyczyniają się do określonych zachowań człowieka zarówno o charakterze wewnętrznym, jak i zewnętrznym. Przy czym mogą to być nawet działania odruchowe. Dopiero głębsza analiza zachowań może przybliżyć badacza do odkrycia pojedynczego motywu działania.

\section{Motywacja do uczenia się}

Motywacja jest jednym z najważniejszych czynników, które mają znaczenie w działalności człowieka. Owa działalność jest pewną aktywnością jednostki, zmierzającej do wykonania z góry ustalonego zadania czy też wielu zadań. Gerd Mietzel za Bernardem Weinerem pisze, że każdy przeżywa pozytywne uczucia, jeżeli może wyjaśnić osiągnięcie swojego sukcesu bodźcami wewnętrznymi. Autor nawiązuje do teorii atrybucji Weinera, która w małym stopniu uwzględnia warunki wpływające na osiąganie sukcesów lub doświadczanie niepowodzeń (Mietzel, 2002: 372-373).

Bożena Tołwińska (2009: 196), wskazuje na szczególne znaczenie motywacji $\mathrm{w}$ ramach organizacji i zarządzania, albowiem poziom zaangażowania pracowników w realizację określonych wcześniej celów decyduje o jej efektywności. Według autorki podobnie jest $\mathrm{z}$ pobudzaniem uczniowskiej motywacji do osiągania celów związanych z uczeniem się.

$Z$ reguły autorzy wyróżniają dwa motywy do uczenia się i są to odpowiednio motywy zewnętrzne i wewnętrzne.

Motywy zewnętrzne zachodzą wówczas, gdy wykonywanie zadań jest środkiem do osiągnięcia jakiegoś celu, np. może być nim zdobycie czegoś wartościowego. Potrzeby ludzkie są różnorodne i dzięki takim działaniom duża ich część może zostać zaspokojona. Według Tołwińskiej uczniowie są zewnętrznie motywowani do uczenia się poprzez np. nagrody, kary, oceny, pochwały odnoszące się do ich osiągnięć czy poprzez przymus (Tołwińska, 2009: 196).

Mietzel (2002: 374) wyjaśnia motywowanie zewnętrzne w kontekście osiągania wyników, które podlegają kontroli z zewnątrz. Motywowany uczeń dąży do osiągnięcia lepszych wyników w nauce, gdyż systematyczna praca ułatwi mu uzyskanie stypendium. W przeciwnym razie nie dostanie upragnionej nagrody.

Motywacja zewnętrzna obejmuje zachowania nakierowane na zewnętrzne skutki, do których należą np. oceny szkolne, różne pochwały, nagrody. Jednak nie są to zachowania nastawione na likwidację wewnętrznego napięcia, które pojawia się np. przy stresujących sytuacjach (Zimbardo i współ., 2010: 62).

Motywy wewnętrzne są bardzo pożądane, ponieważ charakteryzują się wykonywaniem każdej czynności przez człowieka dobrowolnie, bez przymusu. Mietzel 
stwierdza, że motywy wewnętrzne kojarzą się z aktywnością jednostki odczuwającej satysfakcję i radość z możliwości działania. Wykonywanie każdej czynności wynika $z$ własnej i nieprzymuszonej woli, a także sprawia jednostce przyjemność, rzuca nowe, ciekawe wyzwanie (Mietzel, 2002: 374).

Motywacja wewnętrzna pochodzi więc $\mathrm{z}$ „wnętrza” człowieka, który angażuje się w działanie dla samego działania, także pod nieobecność zewnętrznej nagrody. Mogą to być różne rodzaje pracy samoobsługowej, zawodowej, edukacji, a także sposoby spędzania wolnego czasu, które są na ogół motywowane wewnętrznie. Ten rodzaj motywacji ma swoje źródła w wewnętrznych właściwościach jednostki, na przykład cechach osobowościowych czy szczególnych zainteresowaniach (Zimbardo i współ., 2010: 62).

Motywacja wewnętrzna jest więc wartością niezależną, autonomiczną, która $z$ reguły przynosi jednostce wiele satysfakcji. Na podstawie przeprowadzonych badań wynika, że uczniowie mający wysoki poziom tej motywacji, odnoszą w szkole większe sukcesy i mają także większe osiągnięcia. W dodatku mają oni niski poziom lęku związanego ze szkołą, nauczycielami i przedmiotami, a także pozytywnie oceniają własne kompetencje. Te efekty wyników badań są niezależne od poziomu nauczania, płci oraz grupy etnicznej (Zimbardo i współ., 2010: 197).

Ostatnie rozróżnienie przeciwstawia motywy i popędy człowieka wynikające z motywacji świadomej tym, których źródła są umiejscowione w motywacji nieświadomej, albowiem zmotywowani ludzie mogą, ale nie muszą być świadomi popędów czy motywów, które leżą u podstaw ich zachowania - podobnie jak pobudzenie emocjonalne może pojawiać się świadomie lub na poziomie nieświadomym. Według Freuda w nieświadomym umyśle kryją się złożone motywy oparte na traumatycznych doświadczeniach i konfliktach o naturze seksualnej (Zimbardo i współ., 2010: 63).

Ludzie z reguły kierują się wieloma motywami jednocześnie, przy czym ich hierarchia ważności jest labilna i nie zawsze w pełni uświadomiona. Odczuwalne realnie potrzeby mieszają się bardziej lub mniej z określonymi marzeniami, emocje pozytywne z negatywnymi, a zaufanie do siebie z niepewnością (Chodkowski, 2019a: 81).

\section{Metodologia badań własnych}

Przedmiotem tego opracowania jest analiza predyspozycji studentów nauk humanistycznych Uniwersytetu Rzeszowskiego (UR) i studentów nauk ścisłych Politechniki Rzeszowskiej (PR) oraz ich deklaracje na temat wpływu na motywy wyboru studiów. Głównym celem badania jest wzbogacenie wiedzy na temat znaczenia 
wpływu predyspozycji na motywację wyboru kierunków studiów przez studentów reprezentujących dwie główne uczelnie w Rzeszowie.

W nawiązaniu do tematu eksploracji sformułowano następujący problem badawczy: Jak kierunek studiów różnicuje deklaracje badanych w postrzeganiu wpływu predyspozycji na motywację wyboru studiów ze względu na: zainteresowania, autoocenę własnych możliwości intelektualnych, perspektywę wysokich zarobków, szansę na zatrudnienie w kraju, za granicą, program studiów obejmujący przedmioty, które w szkole średniej nie sprawiały trudności, a także program składający się z przedmiotów, z których respondent był dobry w szkole średniej wśród studentów Uniwersytetu Rzeszowskiego i Politechniki Rzeszowskiej?

Do wszystkich przypadków założono hipotezę zerową $\left(\mathrm{H}_{0}\right)$, stwierdzającą brak istotności statystycznej między dwiema grupami reprezentującymi odrębne uczelnie.

Badania przeprowadzono $\mathrm{w}$ grupach studentów rozpoczynających studia na dwóch uczelniach: na kierunkach humanistycznych i na kierunkach ścisłych. Badaniami objęto 400 studentów, w tym 200 studiujących kierunki humanistyczne na Uniwersytecie Rzeszowskim i 200 osób na studiach ścisłych Politechniki Rzeszowskiej, a po weryfikacji odrzucono 17 z powodu niekompletnych odpowiedzi. Do dalszego etapu zakwalifikowano 383 ankiety, w tym 190 respondentów realizujących wybrany kierunek humanistyczny oraz 193 studiujących na wybranych kierunkach ścisłych. Badania przeprowadzono na dwóch uczelniach w czwartym kwartale 2018 r. metodą sondażu diagnostycznego. Techniką badawczą była ankieta, a narzędziem badawczym kwestionariusz ankiety, który został opracowany przez autora artykułu. Odpowiedzi na pytania dotyczące wyboru kierunku studiów sformułowano na podstawie skali Likerta. Studenci wypełniali ankiety bezpłatnie i anonimowo w obecności autora artykułu. Do obliczeń statystycznych wykorzystano nieparametryczny test chi-kwadrat Pearsona.

\section{Wyniki badań}

Badania zostały przeprowadzone w dwóch największych uczelniach województwa podkarpackiego: Uniwersytecie Rzeszowskim - na kierunkach humanistycznych i Politechnice Rzeszowskiej - na kierunkach ścisłych.

$\mathrm{W}$ tabeli 1 przedstawiono liczbę respondentów z podziałem na płeć i uczelnie. Według wyników badań kobiety nieznacznie dominują w obydwu uczelniach i stanowią średnią $62,45 \%$. 
Tabela 1. Płeć badanych według podziału na uczelnie

\begin{tabular}{|c|c|c|c|c|c|c|}
\hline \multirow{2}{*}{ Uczelnia } & \multicolumn{7}{|c|}{ Płeć badanych } \\
\cline { 2 - 7 } & Kobiety & \% & Mężczyźni & \% & Razem & \% \\
\hline Uniwersytet Rzeszowski (UR) & 120 & 63,2 & 70 & 36,8 & 190 & 100 \\
\hline Politechnika Rzeszowska (PR) & 119 & 61,7 & 74 & 38,3 & 193 & 100 \\
\hline
\end{tabular}

Źródło: badania własne

W tabeli 2 przedstawiono wartości procentowe respondentów mieszkających na wsi i w mieście. Ponad 50\% badanych zamieszkuje obszary wiejskie, przy czym wartości z Politechniki są nieco wyższe i wynoszą 63,2\%.

Tabela 2. Miejsce zamieszkania badanych według podziału na uczelnie

\begin{tabular}{|c|c|c|c|c|c|c|}
\hline \multirow{2}{*}{ Uczelnia } & \multicolumn{7}{|c|}{ Miejsce zamieszkania } \\
\cline { 2 - 8 } & Wieś & $\%$ & Miasto & $\%$ & Razem & \% \\
\hline Uniwersytet Rzeszowski (UR) & 97 & 51,1 & 93 & 48,9 & 190 & 100 \\
\hline Politechnika Rzeszowska (PR) & 122 & 63,2 & 71 & 36,8 & 193 & 100 \\
\hline
\end{tabular}

Źródło: badania własne

Wybór drogi życiowej według Jana Poleszczuka (2017: 13) to przede wszystkim te czynniki subiektywne jednostki, do których zaliczają się m.in.: własne preferencje, ambicje, zainteresowania i zdolności, wynikające w sposób pośredni lub bezpośredni ze środowiska życia.

Zainteresowania odgrywają ważną rolę w rozwoju człowieka zarówno w obszarze edukacji, jak i pracy zawodowej. Przeważnie są one powiązane z możliwościami zdrowotnymi organizmu, jego temperamentem, zdolnościami, ambicją, chęcią wykonywania pracy. Zainteresowania to również pewna pasja wzmacniana przez edukację i całożyciowy proces uczenia się człowieka.

Na podstawie wyników badań z 2016 r., dotyczących motywów podjęcia studiów pedagogicznych przez studentów, dominowały trzy motywy: zainteresowania, rozwój osobisty i chęć pogłębienia wiedzy, przy czym zainteresowania uzyskały najwyższe wartości - ponad 65\% (Chodkowski 2019c: 178).

Według wyników w tabeli 3 zainteresowania okazały się czynnikiem decydującym o wyborze studiów u 25,8\% studentów Uniwersytetu Rzeszowskiego, natomiast tylko 9,33\% studentów Politechniki Rzeszowskiej zakreśliło tę opcję.

Zbliżone wyniki uzyskali studenci przy czynnikach, które były ważne, ale nie odgrywały decydującej roli w wyborze kierunku studiów. W tym przedziale większe wartości otrzymali studenci Uniwersytetu Rzeszowskiego (29,5\%) niż Politechniki (25,4\%). 
Tabela 3. Wybór studiów ze względu na zainteresowania według badanych

\begin{tabular}{|c|c|c|c|c|c|c|c|c|}
\hline \multirow{2}{*}{$\begin{array}{l}\text { Wybór studiów } \\
\text { ze względu } \\
\text { na zainteresowania }\end{array}$} & \multicolumn{2}{|c|}{$\begin{array}{l}\text { Uniwersytet } \\
\text { Rzeszowski }\end{array}$} & \multicolumn{2}{|c|}{$\begin{array}{l}\text { Politechnika } \\
\text { Rzeszowska }\end{array}$} & \multicolumn{4}{|c|}{ Chi-kwadrat } \\
\hline & $\begin{array}{l}N= \\
190\end{array}$ & $100 \%$ & $\begin{array}{l}N= \\
193\end{array}$ & $100 \%$ & $\begin{array}{c}\text { Test } \\
\text { niezależności }\end{array}$ & Wartość & df & $\mathbf{p}$ \\
\hline \multirow{2}{*}{$\begin{array}{l}\text { 1. Czynniki, które } \\
\text { były dla Ciebie } \\
\text { zupełnie bez zna- } \\
\text { czenia }\end{array}$} & \multirow{2}{*}{20} & \multirow{2}{*}{10,5} & \multirow{2}{*}{29} & \multirow{2}{*}{15,02} & $\begin{array}{l}\text { Chi-kwadrat } \\
\text { Pearsona }\end{array}$ & 22,931 & 4 &, 000 \\
\hline & & & & & $\begin{array}{l}\text { Iloraz } \\
\text { wiarygodności }\end{array}$ & 23,549 & 4 &, 000 \\
\hline \multirow{2}{*}{$\begin{array}{l}\text { 2. Czynniki, które były } \\
\text { dla Ciebie mało } \\
\text { ważne, ale jednak je } \\
\text { dostrzegałeś, brałeś } \\
\text { pod uwagę }\end{array}$} & \multirow[b]{2}{*}{18} & \multirow[b]{2}{*}{9,5} & \multirow[b]{2}{*}{24} & \multirow[b]{2}{*}{12,43} & \multicolumn{4}{|c|}{ Miary sumaryczne } \\
\hline & & & & & $\begin{array}{l}\text { Nominalna/ } \\
\text { nominalna }\end{array}$ & Wartość & \multicolumn{2}{|c|}{$\begin{array}{l}\text { Istotność } \\
\text { przybliżona }\end{array}$} \\
\hline $\begin{array}{l}\text { 3. Czynniki, które } \\
\text { były średnio ważne }\end{array}$ & 47 & 24,7 & 73 & 37,82 & Phi & ,245 & \multicolumn{2}{|c|}{, 000} \\
\hline $\begin{array}{l}\text { 4. Czynniki, które } \\
\text { były ważne, ale nie } \\
\text { decydujące }\end{array}$ & 56 & 29,5 & 49 & 25,4 & V Kramera & ,245 & \multicolumn{2}{|c|}{,000 } \\
\hline $\begin{array}{l}\text { 5. Czynniki, które } \\
\text { były dla Ciebie } \\
\text { decydujące }\end{array}$ & 49 & 25,8 & 18 & 9,33 & $\begin{array}{l}\text { Współczynnik } \\
\text { kontyngencji }\end{array}$ & ,238 & \multicolumn{2}{|c|}{, 000} \\
\hline
\end{tabular}

Źródło: badania własne

Największą wartość 37,82\% otrzymali studenci z Politechniki, natomiast Uniwersytetu Rzeszowskiego - 24,7\% przy czynnikach, które były średnio ważne.

Na podstawie wyliczonych wartości studenci nauk humanistycznych kierowali się przy wyborze studiów zdecydowanie w większym stopniu zainteresowaniami (jako te czynniki decydujące i ważne) w przeciwieństwie do studentów kierunków ścisłych.

Otrzymane wartości wskazują, że studenci mają poczucie odpowiedzialności, a także mają pewne oczekiwania i świadomie planują przyszłe zatrudnienie pod względem rozwoju zawodowego (Byrne, Flood, 2005: 111-124).

Początek kariery zawodowej wiąże się przeważnie z wysokością wynagrodzenia, które stanowi punkt odniesienia do wszystkiego, co oferuje organizacja i środowisko pracy. Ekwiwalent za wykonanie pracy należy bowiem do jednych z ważniejszych motywatorów. W przypadku grup badawczych studenci kierunków ścisłych mają możliwości uzyskania wyższych zarobków w sektorze prywatnym w stosunku do studentów nauk humanistycznych. 
Tabela 4. Perspektywa wysokich zarobków według badanych

\begin{tabular}{|c|c|c|c|c|c|c|c|c|}
\hline \multirow{2}{*}{$\begin{array}{c}\text { Perspektywa } \\
\text { wysokich zarobków }\end{array}$} & \multicolumn{2}{|c|}{$\begin{array}{l}\text { Uniwersytet } \\
\text { Rzeszowski }\end{array}$} & \multicolumn{2}{|c|}{$\begin{array}{l}\text { Politechnika } \\
\text { Rzeszowska }\end{array}$} & \multicolumn{4}{|c|}{ Chi-kwadrat } \\
\hline & $\begin{array}{l}N= \\
190\end{array}$ & $100 \%$ & $\begin{array}{l}\mathrm{N}= \\
193\end{array}$ & $100 \%$ & $\begin{array}{c}\text { Test } \\
\text { niezależności }\end{array}$ & Wartość & df & p \\
\hline \multirow{2}{*}{$\begin{array}{l}\text { 1. Czynniki, które } \\
\text { były dla Ciebie } \\
\text { zupełnie bez zna- } \\
\text { czenia }\end{array}$} & \multirow{2}{*}{61} & \multirow{2}{*}{32,1} & \multirow{2}{*}{19} & \multirow{2}{*}{9,84} & $\begin{array}{l}\text { Chi-kwadrat } \\
\text { Pearsona }\end{array}$ & 54,152 & 4 &, 000 \\
\hline & & & & & $\begin{array}{l}\text { Iloraz } \\
\text { wiarygodności }\end{array}$ & 56,308 & 4 &, 000 \\
\hline \multirow{2}{*}{$\begin{array}{l}\text { 2. Czynniki, które } \\
\text { były dla Ciebie } \\
\text { mało ważne, ale } \\
\text { jednak je dostrze- } \\
\text { gałeś, brałeś pod } \\
\text { uwagę }\end{array}$} & \multirow[b]{2}{*}{47} & \multirow[b]{2}{*}{24,8} & \multirow[b]{2}{*}{25} & \multirow[b]{2}{*}{13,0} & \multicolumn{4}{|c|}{ Miary sumaryczne } \\
\hline & & & & & $\begin{array}{l}\text { Nominalna/ } \\
\text { nominalna }\end{array}$ & Wartość & \multicolumn{2}{|c|}{$\begin{array}{c}\text { Istotność } \\
\text { przybliżona }\end{array}$} \\
\hline $\begin{array}{l}\text { 3. Czynniki, które } \\
\text { były średnio ważne }\end{array}$ & 45 & 23,7 & 57 & 29,53 & Phi & ,376 & \multicolumn{2}{|c|}{, 000} \\
\hline $\begin{array}{l}\text { 4. Czynniki, które } \\
\text { były ważne, ale nie } \\
\text { decydujące }\end{array}$ & 28 & 14,7 & 63 & 32,63 & V Kramera & ,376 & \multicolumn{2}{|c|}{, 000} \\
\hline $\begin{array}{l}\text { 5. Czynniki, które } \\
\text { były dla Ciebie } \\
\text { decydujące }\end{array}$ & 9 & 4,7 & 29 & 15,0 & $\begin{array}{l}\text { Współczynnik } \\
\text { kontyngencji }\end{array}$ & ,352 & \multicolumn{2}{|c|}{ 000, } \\
\hline
\end{tabular}

Źródło: badania własne

Z tabeli 4 wynika, że 15\% studentów nauk ścisłych w większym stopniu odbiera kształcenie w kontekście perspektywy wyższych zarobków w porównaniu ze studentami nauk humanistycznych, gdzie wartości wynoszą tylko 4,7\%. Natomiast u 32,1\% studentów nauk humanistycznych wysokie zarobki stanowią czynnik zupełnie bez znaczenia. Oznacza to, że bardziej liczą się dla nich inne czynniki typu: zainteresowania, uzdolnienia, pasja, możliwości poszerzenia wiedzy. Studenci wybrali również studia humanistyczne z pełną świadomością tego, że wynagrodzenia w sektorze budżetowym są ciągle na niskim poziomie.

Samoocena jest ważnym elementem w zakresie postrzegania otoczenia, w którym człowiek przebywa. Z reguły odbiera on wszystkie bodźce, do których ma różnoraki, subiektywny stosunek (Chodkowski, 2019b: 203).

Philip Zimbardo wyjaśnia samoocenę (self-esteem) człowieka jako uogólniającą i oceniającą postawę wobec samego siebie. Postawa może silnie wpływać na nasze myśli, nastroje, a także na zachowanie w każdym momencie (Zimbardo, 1999: 542). 
Tabela 5. Autoocena własnych możliwości intelektualnych według badanych

\begin{tabular}{|c|c|c|c|c|c|c|c|c|}
\hline \multirow{2}{*}{$\begin{array}{c}\text { Autoocena własnych } \\
\text { możliwości } \\
\text { intelektualnych }\end{array}$} & \multicolumn{2}{|c|}{$\begin{array}{l}\text { Uniwersytet } \\
\text { Rzeszowski }\end{array}$} & \multicolumn{2}{|c|}{$\begin{array}{l}\text { Politechnika } \\
\text { Rzeszowska }\end{array}$} & \multicolumn{4}{|c|}{ Chi-kwadrat } \\
\hline & $\begin{array}{l}N= \\
190\end{array}$ & $100 \%$ & $\begin{array}{l}N= \\
193\end{array}$ & $100 \%$ & $\begin{array}{c}\text { Test } \\
\text { niezależności }\end{array}$ & Wartość & df & $\mathbf{p}$ \\
\hline \multirow{2}{*}{$\begin{array}{l}\text { 1. Czynniki, które } \\
\text { były dla Ciebie } \\
\text { zupełnie bez zna- } \\
\text { czenia }\end{array}$} & \multirow{2}{*}{15} & \multirow{2}{*}{7,9} & \multirow{2}{*}{12} & \multirow{2}{*}{6,2} & $\begin{array}{l}\text { Chi-kwadrat } \\
\text { Pearsona }\end{array}$ & 11,469 & 4 & ,022 \\
\hline & & & & & $\begin{array}{l}\text { Iloraz } \\
\text { wiarygodności }\end{array}$ & 11,603 & 4 &, 021 \\
\hline \multirow{2}{*}{$\begin{array}{l}\text { 2. Czynniki, które były } \\
\text { dla Ciebie mało } \\
\text { ważne, ale jednak je } \\
\text { dostrzegałeś, brałeś } \\
\text { pod uwagę }\end{array}$} & \multirow[b]{2}{*}{8} & \multirow[b]{2}{*}{4,2} & \multirow[b]{2}{*}{15} & \multirow[b]{2}{*}{7,8} & \multicolumn{4}{|c|}{ Miary sumaryczne } \\
\hline & & & & & $\begin{array}{l}\text { Nominalna/ } \\
\text { nominalna }\end{array}$ & Wartość & \multicolumn{2}{|c|}{$\begin{array}{c}\text { Istotność } \\
\text { przybliżona }\end{array}$} \\
\hline $\begin{array}{l}\text { 3. Czynniki, które } \\
\text { były średnio ważne }\end{array}$ & 45 & 23,7 & 56 & 29,0 & Phi & , 173 & \multicolumn{2}{|c|}{,022 } \\
\hline $\begin{array}{l}\text { 4. Czynniki, które } \\
\text { były ważne, ale nie } \\
\text { decydujące }\end{array}$ & 68 & 35,8 & 80 & 41,5 & V Kramera & ,173 & \multicolumn{2}{|c|}{,022 } \\
\hline $\begin{array}{l}\text { 5. Czynniki, które } \\
\text { były dla Ciebie } \\
\text { decydujące }\end{array}$ & 54 & 28,4 & 30 & 15,5 & $\begin{array}{l}\text { Współczynnik } \\
\text { kontyngencji }\end{array}$ &, 171 & \multicolumn{2}{|c|}{,022 } \\
\hline
\end{tabular}

Źródło: badania własne

Samoocena własnych możliwości intelektualnych stanowi ważny bodziec przy dokonywaniu każdego wyboru. Jednostka postrzega pracę pod względem swoich umiejętności, mając dylemat czy jest w stanie ją prawidłowo wykonać. Często odpowiedź na takie pytanie nie jest jednoznaczna, gdyż brakuje wiedzy, praktyki, a jedynie może ona zahaczać o pewne wyobrażenia, których nie można w chwili wyboru doświadczyć.

Z tabeli 5 wynika, że 28,4\% badanych humanistów zakreśliło autoocenę jako czynnik mający wpływ na motywację wyboru studiów w przeciwieństwie do studentów nauk ścisłych, którzy uzyskali wartość wynoszącą 15,5\%. Natomiast w przypadku autooceny jako czynnika zupełnie bez znaczenia na motywację wyboru, wartości w obydwu grupach są zbliżone i wynoszą odpowiednio 7,9\% dla humanistów i 6,2\% dla studentów kierunków ścisłych.

Ukończenie kształcenia na poziomie co najmniej średnim jest niezbędne do otrzymania kwalifikacji, na podstawie których jednostka podejmie pracę. Programy kształcenia mają być dostosowane do potrzeb rynku pracy i ciągle ulepszane pod względem szybko zmieniających się technologii informacyjno-komunikacyjnych, albowiem sektor informatyczny rozwija się prężnie i ma 
wpływ na wszystkie dziedziny gospodarki. Przekłada się to na coraz więcej stanowisk pracy, na których korzystanie z technologii stanowi podstawę do wykonywania pracy.

Tabela 6. Szanse na zatrudnienie w kraju według badanych

\begin{tabular}{|c|c|c|c|c|c|c|c|c|}
\hline \multirow{2}{*}{$\begin{array}{c}\text { Szanse na zatrudnie- } \\
\text { nie } w \text { kraju }\end{array}$} & \multicolumn{2}{|c|}{$\begin{array}{l}\text { Uniwersytet } \\
\text { Rzeszowski }\end{array}$} & \multicolumn{2}{|c|}{$\begin{array}{l}\text { Politechnika } \\
\text { Rzeszowska }\end{array}$} & \multicolumn{4}{|c|}{ Chi-kwadrat } \\
\hline & $\begin{array}{l}N= \\
190\end{array}$ & $100 \%$ & $\begin{array}{l}N= \\
193\end{array}$ & $100 \%$ & $\begin{array}{c}\text { Test } \\
\text { niezależności }\end{array}$ & Wartość & df & $\mathbf{p}$ \\
\hline \multirow{2}{*}{$\begin{array}{l}\text { 1. Czynniki, które } \\
\text { były dla Ciebie } \\
\text { zupełnie bez zna- } \\
\text { czenia }\end{array}$} & \multirow{2}{*}{42} & \multirow{2}{*}{22,1} & \multirow{2}{*}{18} & \multirow{2}{*}{9,3} & $\begin{array}{l}\text { Chi-kwadrat } \\
\text { Pearsona }\end{array}$ & 30,856 & 4 &, 000 \\
\hline & & & & & $\begin{array}{l}\text { Iloraz } \\
\text { wiarygodności }\end{array}$ & 31,542 & 4 &, 000 \\
\hline \multirow{2}{*}{$\begin{array}{l}\text { 2. Czynniki, które } \\
\text { były dla Ciebie } \\
\text { mało ważne, ale } \\
\text { jednak je dostrze- } \\
\text { gałeś, brałeś pod } \\
\text { uwagę }\end{array}$} & \multirow[b]{2}{*}{39} & \multirow[b]{2}{*}{20,5} & \multirow[b]{2}{*}{23} & \multirow[b]{2}{*}{11,9} & \multicolumn{4}{|c|}{ Miary sumaryczne } \\
\hline & & & & & $\begin{array}{l}\text { Nominalna/ } \\
\text { nominalna }\end{array}$ & Wartość & \multicolumn{2}{|c|}{$\begin{array}{c}\text { Istotność } \\
\text { przybliżona }\end{array}$} \\
\hline $\begin{array}{l}\text { 3. Czynniki, które } \\
\text { były średnio ważne }\end{array}$ & 49 & 25,8 & 41 & 21,2 & Phi & ,284 & \multicolumn{2}{|c|}{,000 } \\
\hline $\begin{array}{l}\text { 4. Czynniki, które } \\
\text { były ważne, ale nie } \\
\text { decydujące }\end{array}$ & 39 & 20,5 & 62 & 32,1 & V Kramera & ,284 & \multicolumn{2}{|c|}{,000 } \\
\hline $\begin{array}{l}\text { 5. Czynniki, które } \\
\text { były dla Ciebie } \\
\text { decydujące }\end{array}$ & 21 & 11,1 & 49 & 25,5 & $\begin{array}{l}\text { Współczynnik } \\
\text { kontyngencji }\end{array}$ & ,284 & \multicolumn{2}{|c|}{, 000} \\
\hline
\end{tabular}

Źródło: badania własne

Według tabeli 6 szanse na zatrudnienie w kraju 25,5\% młodzieży z Politechniki zakreśliła jako czynnik, który miał decydujące znaczenie na wybór studiów. Natomiast 25,8\% studentów Uniwersytetu zakreśliło czynniki, które były średnio ważne. Suma wszystkich czynników o różnej mocy wyboru studiów wyniosła odpowiednio $78,8 \%$ dla studentów Politechniki i 57,4\% dla studentów Uniwersytetu. Oznacza to, że studenci kierunków ścisłych w większym stopniu są zmotywowani do studiowania i wierzą w możliwości zatrudnienia w kraju po ukończeniu studiów. Natomiast zupełnie inaczej przedstawia się sytuacja z zatrudnieniem humanistów. Od wielu lat dostrzega się problem znalezienia pracy u historyków, filozofów, archeologów.

Wejście Polski do Unii Europejskiej 1 maja 2004 r. zapoczątkowało możliwości podejmowania pracy zawodowej we wszystkich państwach członkowskich. Wiele 
osób skorzystało z tej okazji. Przyciągnęły ich wyższe zarobki, lepszy system opieki i pomocy społecznej. Stabilne przepisy prawne i większe bezpieczeństwo ekonomiczne dla mniej uposażonych, a także sprawniejsza infrastruktura społeczno-ekonomiczna w mniejszych obszarach miejskich.

Tabela 7. Możliwość zatrudnienia poza Polską według badanych

\begin{tabular}{|c|c|c|c|c|c|c|c|c|}
\hline \multirow{2}{*}{$\begin{array}{c}\text { Możliwość } \\
\text { zatrudnienia } \\
\text { poza Polską }\end{array}$} & \multicolumn{2}{|c|}{$\begin{array}{l}\text { Uniwersytet } \\
\text { Rzeszowski }\end{array}$} & \multicolumn{2}{|c|}{$\begin{array}{l}\text { Politechnika } \\
\text { Rzeszowska }\end{array}$} & \multicolumn{4}{|c|}{ Chi-kwadrat } \\
\hline & $\begin{array}{l}N= \\
190\end{array}$ & $100 \%$ & $\begin{array}{l}\mathrm{N}= \\
193\end{array}$ & $100 \%$ & $\begin{array}{c}\text { Test } \\
\text { niezależności }\end{array}$ & Wartość & df & $\mathbf{p}$ \\
\hline \multirow{2}{*}{$\begin{array}{l}\text { 1. Czynniki, które } \\
\text { były dla Ciebie } \\
\text { zupełnie bez zna- } \\
\text { czenia }\end{array}$} & \multirow{2}{*}{53} & \multirow{2}{*}{27,9} & \multirow{2}{*}{55} & \multirow{2}{*}{28,5} & $\begin{array}{l}\text { Chi-kwadrat } \\
\text { Pearsona }\end{array}$ & 7,142 & 4 & ,129 \\
\hline & & & & & $\begin{array}{l}\text { Iloraz } \\
\text { wiarygodności }\end{array}$ & 7,205 & 4 & ,125 \\
\hline \multirow{2}{*}{$\begin{array}{l}\text { 2. Czynniki, które } \\
\text { były dla Ciebie } \\
\text { mało ważne, ale } \\
\text { jednak je dostrze- } \\
\text { gałeś, brałeś pod } \\
\text { uwagę }\end{array}$} & \multirow[b]{2}{*}{28} & \multirow[b]{2}{*}{14,7} & \multirow[b]{2}{*}{31} & \multirow[b]{2}{*}{16,1} & \multicolumn{4}{|c|}{ Miary sumaryczne } \\
\hline & & & & & $\begin{array}{c}\text { Nominalna/ } \\
\text { nominalna }\end{array}$ & Wartość & \multicolumn{2}{|c|}{$\begin{array}{l}\text { Istotność } \\
\text { przybli- } \\
\text { żona }\end{array}$} \\
\hline $\begin{array}{l}\text { 3. Czynniki, które } \\
\text { były średnio ważne }\end{array}$ & 30 & 15,8 & 44 & 22,8 & Phi & ,137 & & \\
\hline $\begin{array}{l}\text { 4. Czynniki, które } \\
\text { były ważne, ale nie } \\
\text { decydujące }\end{array}$ & 42 & 22,1 & 25 & 12,9 & V Kramera & ,137 & & \\
\hline $\begin{array}{l}\text { 5. Czynniki, które } \\
\text { były dla Ciebie } \\
\text { decydujące }\end{array}$ & 37 & 19,5 & 38 & 19,7 & $\begin{array}{l}\text { Współczynnik } \\
\text { kontyngencji }\end{array}$ & ,135 & & \\
\hline
\end{tabular}

Źródło: badania własne

Na podstawie badań przeprowadzonych przez Work Service za pracą wyjeżdżają głównie mężczyźni (78,7\%), kobiety zaś stanowią 62,2\%. Jednak biorąc pod uwagę inne okoliczności, typu sprawy rodzinne, edukacja, leczenie i rehabilitacja, to ogółem jednak za granicą przebywa więcej kobiet $(51,1 \%)$ niż mężczyzn (48,9\%). Decyzję o emigracji częściej podejmują z kolei mieszkańcy miast. Ponad $60 \%$ osób w wieku od 18 do 24 lat jest zainteresowanych emigracją i podjęciem pracy za granicą (Emigracja..., 2015).

Według wyników badań dotyczących możliwości zatrudnienia poza Polską zawartych w tabeli 7 najwyższe wartości są w przedziale pierwszym (czynniki, które były dla Ciebie zupełnie bez znaczenia), dla studentów UR 27,9\% i 28,5\% dla respondentów z PR. Natomiast sumując czynniki, które były w różnym stopniu de- 
cydujące, wartości przekroczyły 50\% i wyniosły one odpowiednio dla studentów UR - 57,4\% i 55,4\% dla PR.

Młodzi ludzie są świadomi swojego obszaru kształcenia, planują karierę zawodową i chcą otrzymywać odpowiedni ekwiwalent za wykonaną pracę. Dlatego w niektórych przypadkach biorą pod uwagę także wyjazd ekonomiczny za granicę.

Tabela 8. Program studiów obejmujący przedmioty, które w szkole średniej nie sprawiały trudności w opinii badanych

\begin{tabular}{|c|c|c|c|c|c|c|c|c|}
\hline \multirow{2}{*}{$\begin{array}{c}\text { Program } \\
\text { studiów obejmujący } \\
\text { przedmioty, które } \\
\text { w szkole średniej } \\
\text { nie sprawiały } \\
\text { trudności }\end{array}$} & \multicolumn{2}{|c|}{$\begin{array}{l}\text { Uniwersytet } \\
\text { Rzeszowski }\end{array}$} & \multicolumn{2}{|c|}{$\begin{array}{l}\text { Politechnika } \\
\text { Rzeszowska }\end{array}$} & \multicolumn{4}{|c|}{ Chi-kwadrat } \\
\hline & $\begin{array}{l}N= \\
190\end{array}$ & $100 \%$ & $\begin{array}{l}N= \\
193\end{array}$ & $100 \%$ & $\begin{array}{c}\text { Test } \\
\text { niezależności }\end{array}$ & Wartość & df & $\mathbf{p}$ \\
\hline \multirow{2}{*}{$\begin{array}{l}\text { 1. Czynniki, które } \\
\text { były dla Ciebie } \\
\text { zupełnie bez zna- } \\
\text { czenia }\end{array}$} & \multirow{2}{*}{13} & \multirow{2}{*}{6,8} & \multirow{2}{*}{31} & \multirow{2}{*}{16,1} & $\begin{array}{l}\text { Chi-kwadrat } \\
\text { Pearsona }\end{array}$ & 22,069 & 4 &, 000 \\
\hline & & & & & $\begin{array}{l}\text { Iloraz } \\
\text { wiarygodności }\end{array}$ & 22,502 & 4 &, 000 \\
\hline \multirow{2}{*}{$\begin{array}{l}\text { 2. Czynniki, które } \\
\text { były dla Ciebie } \\
\text { mało ważne, ale } \\
\text { jednak je dostrze- } \\
\text { gałeś, brałeś pod } \\
\text { uwagę }\end{array}$} & \multirow[b]{2}{*}{14} & \multirow[b]{2}{*}{7,4} & \multirow[b]{2}{*}{23} & \multirow[b]{2}{*}{11,9} & \multicolumn{4}{|c|}{ Miary sumaryczne } \\
\hline & & & & & $\begin{array}{l}\text { Nominalna/ } \\
\text { nominalna }\end{array}$ & Wartość & \multicolumn{2}{|c|}{$\begin{array}{c}\text { Istotność } \\
\text { przybliżona }\end{array}$} \\
\hline $\begin{array}{l}\text { 3. Czynniki, które } \\
\text { były średnio ważne }\end{array}$ & 34 & 17,9 & 46 & 23,8 & Phi & ,240 & \multicolumn{2}{|c|}{, 000} \\
\hline $\begin{array}{l}\text { 4. Czynniki, które } \\
\text { były ważne, ale nie } \\
\text { decydujące }\end{array}$ & 58 & 30,5 & 56 & 29 & V Kramera & ,240 & \multicolumn{2}{|c|}{, 000} \\
\hline $\begin{array}{l}\text { 5. Czynniki, które } \\
\text { były dla Ciebie } \\
\text { decydujące }\end{array}$ & 71 & 37,4 & 37 & 19,2 & $\begin{array}{l}\text { Współczynnik } \\
\text { kontyngencji }\end{array}$ & ,233 & \multicolumn{2}{|c|}{, 000} \\
\hline
\end{tabular}

Źródło: badania własne

Nauczanie przynosi lepsze efekty, kiedy uczeń nie ma trudności w opanowaniu całego materiału. Pomagają temu różne czynniki, jak np. uzdolnienia, zainteresowania, chęć poszerzania wiedzy, pasja, przyjemność. Szybkie przyswajanie wiedzy wzmacnia jednostkę, która odczuwa zadowolenie z otrzymywania bardzo dobrych oceń. To z kolei wpływa pozytywnie na jej motywację do następnych dokonań.

Kolejne badanie dotyczyło programu studiów obejmujących przedmioty, które w szkole średniej nie sprawiały respondentom trudności. Na podstawie danych 
z tabeli 8 studenci z Uniwersytetu Rzeszowskiego uzyskali wyższe wartości wśród czynników, które były decydujące $(37,4 \%)$ i te, które były ważne, ale nie decydujące (30,5\%). Natomiast studenci z Politechniki uzyskali wartości nieco niższe, bo w pierwszej opcji było tylko 19,2\%, a w drugiej 29\%. Wygląda na to, że dla humanistów ważne jest poszerzanie wiedzy na studiach z przedmiotów, z których nie mieli problemu w szkole średniej. Z drugiej strony przedmioty humanistyczne zawierają dużo szerszy zakres materiału, który lepiej jest poszerzany i zarazem przyswajany na fundamentach zdobytej wiedzy w szkole średniej w przeciwieństwie do przedmiotów ścisłych.

Tabela 9. Przedmioty na studiach, z których w szkole byłem dobry według badanych

\begin{tabular}{|c|c|c|c|c|c|c|c|c|}
\hline \multirow{2}{*}{$\begin{array}{l}\text { Przedmioty na } \\
\text { studiach, z których } \\
\text { byłem dobry } \\
\text { w szkole średniej }\end{array}$} & \multicolumn{2}{|c|}{$\begin{array}{l}\text { Uniwersytet } \\
\text { Rzeszowski }\end{array}$} & \multicolumn{2}{|c|}{$\begin{array}{l}\text { Politechnika } \\
\text { Rzeszowska }\end{array}$} & \multicolumn{4}{|c|}{ Chi-kwadrat } \\
\hline & $\begin{array}{l}N= \\
190\end{array}$ & $100 \%$ & $\begin{array}{l}N= \\
193\end{array}$ & $100 \%$ & $\begin{array}{c}\text { Test } \\
\text { niezależności }\end{array}$ & Wartość & df & $\mathbf{p}$ \\
\hline \multirow{2}{*}{$\begin{array}{l}\text { 1. Czynniki, które } \\
\text { były dla Ciebie } \\
\text { zupełnie bez zna- } \\
\text { czenia }\end{array}$} & \multirow{2}{*}{17} & \multirow{2}{*}{8,9} & \multirow{2}{*}{26} & \multirow{2}{*}{13,5} & $\begin{array}{l}\text { Chi-kwadrat Pe- } \\
\text { arsona }\end{array}$ & 43,476 & 4 &, 000 \\
\hline & & & & & $\begin{array}{l}\text { Iloraz } \\
\text { wiarygodności }\end{array}$ & 44,572 & 4 &, 000 \\
\hline \multirow{2}{*}{$\begin{array}{l}\text { 2. Czynniki, które } \\
\text { były dla Ciebie } \\
\text { mało ważne, ale } \\
\text { jednak je dostrze- } \\
\text { gałeś, brałeś pod } \\
\text { uwagę }\end{array}$} & \multirow[b]{2}{*}{6} & \multirow[b]{2}{*}{3,2} & \multirow[b]{2}{*}{18} & \multirow[b]{2}{*}{9,3} & \multicolumn{4}{|c|}{ Miary sumaryczne } \\
\hline & & & & & $\begin{array}{l}\text { Nominalna/ } \\
\text { nominalna }\end{array}$ & Wartość & \multicolumn{2}{|c|}{$\begin{array}{c}\text { Istotność } \\
\text { przybliżona }\end{array}$} \\
\hline $\begin{array}{l}\text { 3. Czynniki, które } \\
\text { były średnio ważne }\end{array}$ & 34 & 17,9 & 77 & 39,9 & Phi & ,337 & \multicolumn{2}{|c|}{, 000} \\
\hline $\begin{array}{l}\text { 4. Czynniki, które } \\
\text { były ważne, ale nie } \\
\text { decydujące }\end{array}$ & 76 & 40,0 & 46 & 23,8 & V Kramera & ,337 & \multicolumn{2}{|c|}{,000 } \\
\hline $\begin{array}{l}\text { 5. Czynniki, które } \\
\text { były dla Ciebie } \\
\text { decydujące }\end{array}$ & 57 & 30,0 & 26 & 13,5 & $\begin{array}{l}\text { Współczynnik } \\
\text { kontyngencji }\end{array}$ & ,319 & \multicolumn{2}{|c|}{, 000} \\
\hline
\end{tabular}

Źródło: badania własne

Każdy człowiek ma różne uzdolnienia. Jeden ma predyspozycje do nauk ścisłych, a drugi lepiej przyswaja wiedzę humanistyczną. Niezależnie od tego wyuczona teoria zwiększa szansę na znalezienie pracy. Wskazane jest więc, aby uczeń rozwijał się w takiej dziedzinie, w której ma szczególne predyspozycje, a kontynuacja nauki z przedmiotów tych samych lub pokrewnych, z którymi nie było wcześniej problemów, zaowocuje lepszymi efektami. 
W tabeli 9 zaprezentowano wyniki badania wyboru studiów ze względu na przedmioty, z których w szkole respondent był dobry. Najwyższe wartości procentowe otrzymali respondenci z Uniwersytetu Rzeszowskiego, odpowiednio 40\% (czynniki były ważne, ale nie decydujące) i 30\%, gdzie czynniki te były decydujące. Natomiast w przypadku studentów Politechniki najwyższe wartości uzyskały czynniki, które były średnio ważne, prawie 40\% i 23,8\% - czynniki, które były ważne, ale nie decydowały o wyborze kierunku studiów.

U studentów Uniwersytetu Rzeszowskiego 87,9\% wszystkich czynników w różnym stopniu zadecydowało o wyborze kierunku studiów, natomiast nieco mniej, bo 77,2\% uzyskali studenci Politechniki Rzeszowskiej. Wynika z tego badania, że studenci z Uniwersytetu wzięli pod uwagę przedmioty, z których byli dobrzy w większym stopniu o około $10 \%$ w stosunku do studentów z Politechniki.

\section{Konkluzja}

W podsumowaniu badań można stwierdzić, że kobiety stanowią zdecydowaną większość badanych, a także więcej studentów mieszka na wsi. W następnych wynikach badań respondenci zaznaczyli wpływ swoich predyspozycji na motywację podjęcia kierunku studiów.

Wyniki badań wskazują na różnice według predyspozycji studentów, które generują wpływ na motywację wyboru studiów wśród studentów Uniwersytetu Rzeszowskiego i Politechniki Rzeszowskiej w następujących kategoriach:

- predyspozycje: zainteresowania, autoocena własnych możliwości intelektualnych;

- zawody: perspektywa wysokich zarobków, możliwości zatrudnienia w kraju i za granicą;

- oferta uczelni, np. programowa - program studiów obejmujący przedmioty, które w szkole średniej nie sprawiały trudności, a także takie przedmioty, z których w szkole średniej respondent był dobry.

$\mathrm{Na}$ podstawie obliczenia nieparametrycznego chi-kwadrat istotne statystycznie różnice wykazuje sześć wyników badań i są to odpowiednio:

- zainteresowania (tab. 3), gdzie siła związku jest na małym poziomie $(0,238)$. Wpływ predyspozycji na motywację wyboru studiów jest decydujący w większym zakresie dla studentów Uniwersytetu Rzeszowskiego, biorąc pod uwagę sumę trzech czynników: średnio ważne, ważne i decydujące, które wynoszą odpowiednio 80\% dla UR i 72,55\% dla PR; 
- perspektywa wysokich zarobków (tab. 4), gdzie siła związku jest na średnim poziomie $(0,352)$, wpływ predyspozycji jest decydujący w większym zakresie dla studentów Politechniki - 77,16\%, a dla UR - 43,1\%;

- autoocena własnych możliwości intelektualnych (tab. 5), gdzie siła związku jest na małym poziomie $(0,171)$, natomiast wpływ predyspozycji jest decydujący dla studentów Uniwersytetu i wynosi $87,9 \%$ w stosunku do studentów Politechniki - 86\%;

- szansa na zatrudnienie w kraju (tab. 6), gdzie siła związku jest na małym poziomie $(0,284)$, wpływ predyspozycji jest decydujący dla studentów Politechniki - 78,8\%, a $57,4 \%$ dla UR;

- program studiów obejmujący przedmioty, które w szkole średniej nie sprawiały trudności (tab. 8), gdzie siła związku jest na małym poziomie $(0,233)$, wpływ predyspozycji jest decydujący dla studentów UR - 85,8\%, a dla PR - 72\%;

- przedmioty na studiach, z których byłem dobry w szkole średniej (tab. 9), gdzie siła związku jest na średnim poziomie $(0,319)$, natomiast wpływ predyspozycji jest decydujący dla studentów UR - 87,9\% w porównaniu ze studentami PR - 77,2\%.

W tych przypadkach wartość $p$ jest mniejsze od 0,05 , dlatego założoną hipotezę $\mathrm{H}_{0}$ odrzuca się i przyjmuje hipotezę alternatywną $\mathrm{H}_{1}$

W jednym badaniu - możliwości zatrudnienia poza Polską - zróżnicowanie między grupami wynosi poniżej 95\%, a więc $p$ jest większe od 0,05, dlatego nie ma podstawy do odrzucenia hipotezy zerowej. W tym przypadku wpływ predyspozycji na motywację wyboru studiów jest decydujący dla studentów UR - 57,4\% w porównaniu ze studentami PR - 55,4\%.

Wyniki badań poszerzają wiedzę na temat wpływu predyspozycji na motywację wyboru kierunków studiów. Studenci kierują się własnymi zainteresowaniami, uzdolnieniami, autooceną, a także patrzą na swoje plany zawodowe przez pryzmat dużego bezrobocia, zwłaszcza w obszarach wiejskich i małomiasteczkowych województwa podkarpackiego.

Szewczuk stwierdza, że pochodzenie społeczne jednostki nie odgrywa istotnej roli w zdobywaniu mistrzostwa $\mathrm{w}$ danej dziedzinie nauki czy pracy. Ważne jest wychowanie, a szczególnie samowychowanie. Autor wymienia szereg konkretnych zmiennych, do których zalicza właściwości kory mózgowej czy właściwości osobowości, np. umiejętność samosterowania, pokonywania trudności, aspiracje, wytrwałość, cierpliwość, sprzyjające warunki środowiskowe (atmosfera domu rodzinnego, szkoły), właściwe stosunki międzyludzkie. Autor zaznacza, że w rozwoju uzdolnień jednostki są również ważne: głębokie zainteresowania, intensywna praca i pozytywne warunki społeczne (Szewczuk 1993: 995-996). 
Reasumując, zaleca się przeprowadzenie podobnych badań w celu dalszego diagnozowania postaw prozawodowych młodzieży w zakresie różnych wpływów na motywację wyboru kierunku studiów i związanych z tym planów zawodowych. Wyniki badań mogą być wykorzystane przez doradców zawodowych, szkolnych, a także wykładowców i rodziców. Motywy, jakimi kierują się studenci, mogą być również pomocne w tworzeniu nowych programów kształcenia, które będą lepiej dostosowane do potrzeb zmieniającego się rynku pracy.

\section{Bibliografia}

Byrne M., Flood B. (2005), A Study of Accounting Students' Motives, Expectations and Preparedness for Higher Education, Journal of Further and Higher Education, 2 (29).

Chodkowski Z. (2019a), Adaptacja człowieka do środowiska pracy, Rzeszów.

Chodkowski Z. (2019b), Autoocena własnych szans funkcjonowania zawodowego po ukończeniu studiów pedagogicznych, Szkoła - Zawód - Praca, nr 17, s. 201-216.

Chodkowski Z. (2019c), Plany zawodowe studentów Pedagogiki Uniwersytetu Rzeszowskiego w kontekście miejsca ich zamieszkania, Zarządzanie Publiczne, 2(46), s. 171-187.

Emigracja zarobkowa Polaków. Wyjeżḋa coraz więcej wykształconych (2015), http://www.money.pl/gospodarka/wiadomosci/artykul/emigracja-zarobkowa-polakow-wyjezdza-co-raz,43,0,1864235.html, dostęp: 20.04.2020.

Farnicka M., Liberska H. (2014), Tworzenie środowiska sprzyjającego uczeniu się - analiza wybranych czynników, Teraźniejszość - Człowiek - Edukacja, nr 67(3).

Griffin R. (1997), Podstawy zarządzania organizacjami, Warszawa.

Kim Y., Mok S.Y., Seidel T. (2020), Parental Influences on Immigrant Students' Achievement-Related Motivation and Achievement: A Meta-Analysis, Educational Research Review, 30.

Kocowski T. (1993), Motywacja, [w:] W. Pomykało (red.), Encyklopedia pedagogiczna, Warszawa, s. $384-389$.

Kozioł L. (2002), Motywacja w pracy. Determinanty ekonomiczno-organizacyjne, Warszawa-Kraków.

Mantica A., Moneva J., Malbas M. (2020), Family Status and Self-Motivation in Studies, International Research in Education, vol. 8, no. 1.

Mietzel G. (2002), Psychologia kształcenia, Gdańsk.

Okoń W. (1998), Nowy słownik pedagogiczny, Warszawa.

Poleszczuk J. (2017), Decyzje edukacyjne maturzystów. Kontekst społeczny i indywidualne postawy młodzieży Białegostoku wobec wykształcenia wyższego, Pogranicze. Studia Społeczne, t. XXXI.

Reykowski J. (1992), Procesy emocjonalne. Motywacja. Osobowość, [w:] T. Tomaszewski (red.), Psychologia ogólna, Warszawa.

Sadowski R. (2019), Czynniki wplywające na wybór studiów. Raport, https://biznes.newseria.pl/biuro-prasowe/edukacja/czynniki-wplywajace-na,b1341706904, dostęp: 30.10.2020.

Stoner J.A.F., Freeman R.E., Gilbert D.R. (2011), Kierowanie, Warszawa.

Szewczuk W. (1997), Zdolności i uzdolnienia, [w:] W. Pomykało (red.), Encyklopedia pedagogiczna, Warszawa, 
Tołwińska B. (2009), Motywacja dzieci do uczenia się (problemy dzieci, rola dorosłych), [w:] J. Izdebska i J. Szymanowska (red.), Wielowymiarowość przestrzeni życia współczesnego dziecka, Białystok. Zimbardo P.G. (1999), Psychologia i życie, Warszawa.

Zimbardo P.G., Johnson R.L., McCann V. (2010), Psychologia. Kluczowe Koncepcje. Motywacja i uczenie się, Warszawa. 